\section{Groundcover Materials Improve Quality and Storability of 'Aroma' Apples}

\author{
Ibrahim I. Tahir, ${ }^{1}$ Eva Johansson, and Marie E. Olsson \\ Department of Crop Science. The Swedish University of Agricultural Sciences, \\ P.O. Box 44, SE-230 53 Alnarp, Sweden
}

Additional index words. groundcover material systems, GCMSs, mulching, herbicides, storage, quality, Malus domestica

\begin{abstract}
To decrease the unfavorable effects of herbicides on human health and on the environment, new sustainable mulching methods have been developed. These methods aim to impede weed growth and also result in good yield and high fruit quality. The objective of the present study was to investigate the effects of the replacement of conventional methods (chemical treatments or mechanical) with different groundcover material systems (GCMSs) that use aluminum, bark and black polypropylene on 'Aroma' apple (Malus domestica) fruit maturity and quality, and fruit resistance to bruising and decay. The experiment was carried out from 1995 to 2001. Compared with conventional mulching methods, aluminum mulching was found to control annual weeds more effectively, to increase soil temperature, light reflection, yield, and fruit weight, to decrease bruise occurrence, to intensify and saturate the red coloration of apples, and to increase firmness and acid and sugar contents, resistance to storage disorders and decay after storage and shelf life. The other two used GCMSs, bark and black polypropylene also influenced many yield and quality parameters. However, less positive influences on the different parameters were found for bark compared with aluminum, and the use of black propylene was not favorable compared with the conventional mulching methods. Generally, decreased starch content at early picking dates was found for apples grown with GCMSs, indicating an earlier ripening for these apples compared with apples grown with a conventional mulching system. In summary, aluminum mulching was found to be the best alternative mulching method for production of 'Aroma' apples.
\end{abstract}

Weeds around the base of the apple (Malus domestica) trees reduce growth; affect fruit quality by competing for moisture and nutrients, and harbor insects, diseases and rodents (Ericsson, 1987). Therefore, weed control by conventional methods (mechanical cultivation or chemical herbicide) has long been recognized. Because of higher work costs of mechanical cultivation and risky effect of chemical herbicides on human health and ground water, there is a need to replace these two conventional weed control methods with more sustainable, safe, and economic methods, such as using of ground cover materials.

Investigations on the use of different groundcover management systems (GCMSs) as an alternative to conventional mulching (Andris et al., 1998; Darbellay, 1997; Mathieu and Aure, 2000; Mika et al., 1998; Oliveira and Merwin, 2001; Zhiqiang et al., 1999; Weibel, 1996) have shown different results. For example, using herbicides alone was less effective in controlling weeds than application of GCMSs (Rifai et al., 2002) while organic mulches could not totally prevent weed growth as effectively as herbicide sprays (Mika et al., 1998).

Different mulching methods also have various effects on yield and fruit quality. Some studies confirm that organic mulches increase the

Received for publication 16 Feb. 2005. Accepted for publication $31 \mathrm{Mar}$. 2005. Our grateful thank to Boel Sandskär, Helena Person Hovmalm and Erland Liljeroth for their guidance.

${ }^{1}$ To whom correspondence should be addressed; e-mailibrahim.tahir@vv.slu.se. yield compared with using herbicides (Darbellay, 1997; Wieniarska et al., 2000), while one study shows that spraying with herbicide results in higher yield than organic mulches such as bark (Weibel, 1996).

GCMSs decreased total soluble solid concentration in 'Gala' apple (Fausett and Rom, 2001), increased it in 'Royal Delicious' apples (Bhutani et al., 1995), and did not show, in another study, any significant effect on fruit external or internal quality (Mage and Skogerbo, 1992). Because of these rare and contradictory studies, effects of GCMSs on fruit quality and storability need more investigations.

Due to its good adaptation to the Swedish conditions, 'Aroma' is one of the major apple cultivar produced in Sweden. Problems such as relatively high bruise sensitivity, weak resistance to some pathogens and poor coloration at optimum harvesting period, can however affect the quality and the grower incomes (Dris et al., 1999; Meberg et al., 2000; Ystaas and Froynes, 1993). Some of these problems may be solved through better-developed orchard management, such as fertigation, pruning and mulching.

The aim of this project was to study the effects of different mulching methods on yield, fruit maturity and quality, and fruit resistance to bruising and pathogen (mostly Peziculla spp.) in 'Aroma'.

\section{Materials and Methods}

Experimental design. The experiment was conducted at Kivik research station in southern
Sweden from June 1995 to December 2001, in a 6-year-old apple orchard, Malus domestica 'Aroma' on rootstock MM106. A randomized block design comprising four replications and four trees per replication (spacing was $2 \mathrm{~m}$ apart in the row and $4 \mathrm{~m}$ between rows, 1250 trees/ha).

Preharvest treatments. Five different mulching methods were tested on 'Aroma' trees. Two conventional methods, herbicide and mechanical mulching, were applied. For herbicide, a mixture of glyphosate $\left[360 \mathrm{~g} \cdot \mathrm{L}^{-1}\right.$ Roundup (N-physphomethylglycine); Monsanto, Belgium] and Dikvat $\left[200 \mathrm{~g} \cdot \mathrm{L}^{-1}\right.$ Reglone (1.1 ethylene-2.2 bipyridyldiyldibromid); Syngenta, Sweden) was sprayed to the soil twice a year (May and July). Herbicide dose was 3 $\mathrm{L} \cdot \mathrm{ha}^{-1}$, sprayed area, liquid volume rate 320 $\mathrm{L} \cdot \mathrm{ha}^{-1}$, and travel speed was $3.5 \mathrm{~km} \cdot \mathrm{h}^{-1}$. During 1998-2001, Dikvat was replaced with MCPA [Duplosan super(4-chloro-2-methylphenoxy); BASF, Sweden]. Mechanical mulching was achieved by monthly soil cultivation (May to August) by rotary hoe, rototiller. Some weeds were removed by hand several times during the season.

Three groundcover material systems (GCMSs) were applied. Soil was covered with a black plastic sheet (black polypropylene (BP), $0.5 \mathrm{~mm}$ thickness and $3 \mathrm{~m}$ width, Lotico, Sweden), or with a layer ( $20 \mathrm{~cm}$ thick) of one year old chopped pine bark, or with a plastic sheet (aluminized plastic film, $0.06 \mathrm{~mm}$ thickness, $3 \mathrm{~m}$ width, Lotico, Sweden). Aluminum, which used with white reflective side up and gray side down to the ground, and BP, were changed every 2 years, while more bark was add every year. Treatments covered the soil as far as one meter of both sides of the tree.

Standard orchard management was applied. Weeds were visually assessed in each replication $(\mathrm{n}=20)$ using a grading scale where $1=$ very few weeds, $2=$ few weeds, $3=$ visible weed growth, $4=$ dense weeds, and $5=$ very dense weeds. Soil temperature and light reflection were only measured during two seasons to establish GCMSs effects on these parameters. Soil temperature was measured by temperature logs (Tiny Talk; Intab, Sweden) at a depth of 20 to $25 \mathrm{~cm}$ in all replications $(\mathrm{n}=20)$, and $25 \mathrm{~cm}$ from the tree trunk. Data was registered every fifth minute, daily during 1995 and 1996 from August to January. Light reflection was registered (June to September 1995 and 1996) monthly in cloudless days by a light meter (LI188; LI-COR, Fredrikssund, Denmark) that was fixed about $1 \mathrm{~m}$ above the ground and in the middle of the plantation row of each replication $(\mathrm{n}=20)$. Stem diameter was measured $20 \mathrm{~cm}$ above the bud union in 1995 and 1999. Tree height and canopy spread (average of acrossrow and along-row measures) were recorded at the end of the experiment (2001). Changes in trunk cross-sectional area $(\mathrm{TCSA}=((\mathrm{stem}$ diameter $/ 2)^{2} \times \Pi$ ) and differences between trees size were used to assess treatments effect on vegetative growth.

Harvesting and postharvest treatments. Three times a week, two fruit were picked from each tree (four trees per four replications per treatment, $n=160$ ) and starch index was used 
as a criterion for determination of commercial harvesting date. Starch score was evaluated by dipping a slide of the fruit, cut at the equator, in an iodine solution, and using a grading scale where 1 = full staining, 2 = clear of stain in seed cavity, $3=$ clear of stain in halfway to vascular area, $4=$ core nearly free from staining, $5=$ core free from staining, $6=$ clear through the area including vascular bundles, $7=$ half of flesh clear, $8=$ staining just under skin, and $9=$ free of starch (no stain) (Ericsson, 1982).

Fruit of each tree were picked at commercial harvest date (starch index 4 to 5), weighed and counted. A total of 100 fruit from each treatment were stored at 2 to $3{ }^{\circ} \mathrm{C}$ and $90 \% \mathrm{RH}$, for 4 months, and then $50 \%$ of these apples were kept at room temperature $(70 \% \mathrm{RH})$ for another week after storage for studies of shelf life. Fruit quality was evaluated on five fruit per tree (four replications per treatment and four trees each, $n=400)$, at harvest, and five fruit per replication (four replications per treatment, $\mathrm{n}=100$ ) after storage and after shelf life. Fruit firmness was determined with a penetrometer (plunger diameter of $11.1 \mathrm{~mm}$, model FT 327; Effigi, Italy) on opposite sides of each fruit, soluble solid concentration (SSC) was measured by a refractrometer (Atago, Japan) and fruit acidity was analyzed by titration of fruit juice as Malic acid with $0.05 \mathrm{~N} \mathrm{NaOH}$ to pH 8.1 (radiometer PHM64). Fruit coloration was measured through the hue angle using a colorimeter chromameter (model CR200; Minolta Camera Co, Ltd., Osaka, Japan) with a 8-mm-diameter window. Measurements were conducted on three spots per fruit, and expressed as hue angle $\left(\mathrm{h}^{\circ}\right)$ (where $0^{\circ}=$ redpurple, $90^{\circ}=$ yellow, $180^{\circ}=$ bluish-green, and $270^{\circ}=$ blue) (McGuire, 1992).

Fruit bruise susceptibility was assessed by dropping fruit (two fruit per tree, $n=160$ ) from $30 \mathrm{~cm}$ on a wooden table, using fruit of similar weights (125 to $140 \mathrm{~g}$ ) to avoid the effect of fruit weight on bruise occurrence. Fruit sensitivity was quantified as bruise weight percentage (BWP) (Ericsson and Tahir 1996a, 1996b). The percentage of decayed fruit, caused by storage rots (Pezicula spp. and Penicillium expansum) was determined by visual examination after storage and shelf life. The type of pathogens was determined according to Rein (1996).

Statistical analyses. The results were expressed as the mean \pm standard deviation, and analyzed with Microsoft Excel. Data were analyzed also by analysis of variance (ANOVA). Five different mulching methods, seven seasons and the interaction between method and season were the factors for yield, fruit weight, pre- and poststorage fruit quality, and the incidence of storage disorders.

\section{Results}

Weed control. Aluminum and black polypropylene controlled annual weeds in a more effective way than other mulching methods (Fig. 1). However, weeds were removed by hand from the holes cut in these two treatments. Bark mulching had a weaker effect on weed growth than mechanical cultivation.

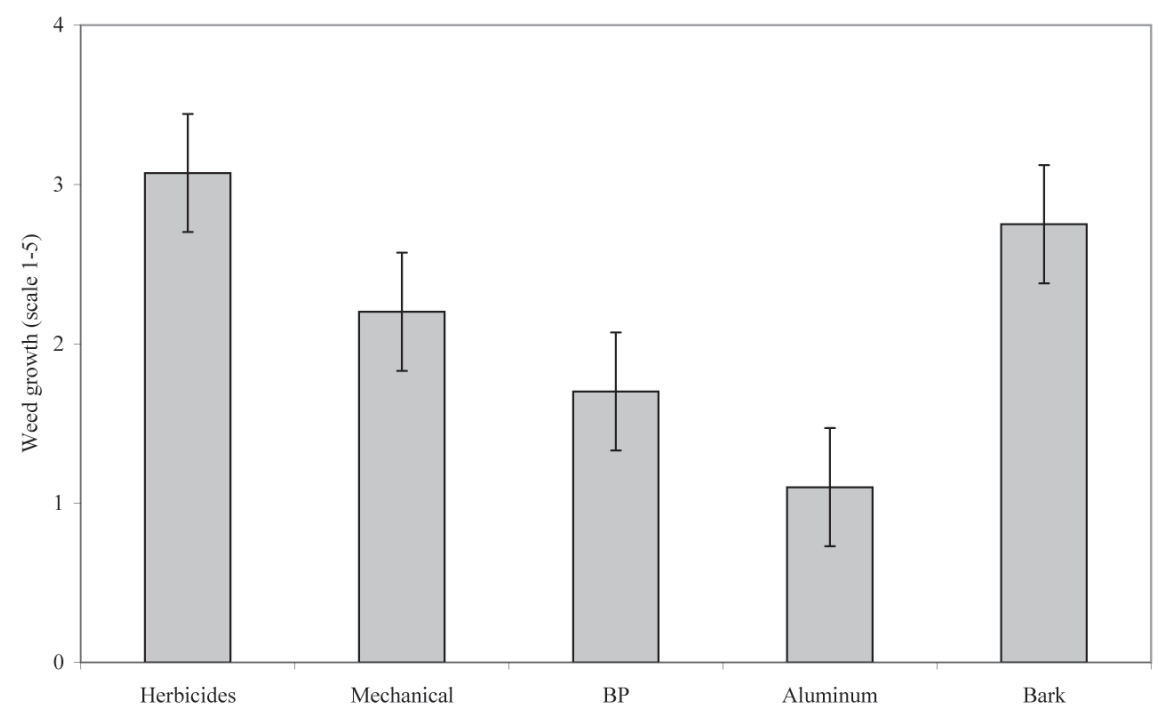

Fig. 1. Weed growth in different mulching methods, 1995-2001. Weed growth were determined by using scale from 1 to $5,1=$ very few weeds, 2 = few weeds, 3 = visible weed growth, $4=$ dense weeds, and $5=$ very dense weeds. Bars represent \pm SD. Values are means of four replications of four trees, $\mathrm{n}=20$. (F value: mulching methods, $73.9^{* * *}$; seasons, $1.48^{\mathrm{NS}}$; mulching $\times$ seasons, $\left.0.78^{\mathrm{NS}}\right)$. ${ }^{\mathrm{NS}, * * *}$ Nonsignificant or significant at $P=0.01$.
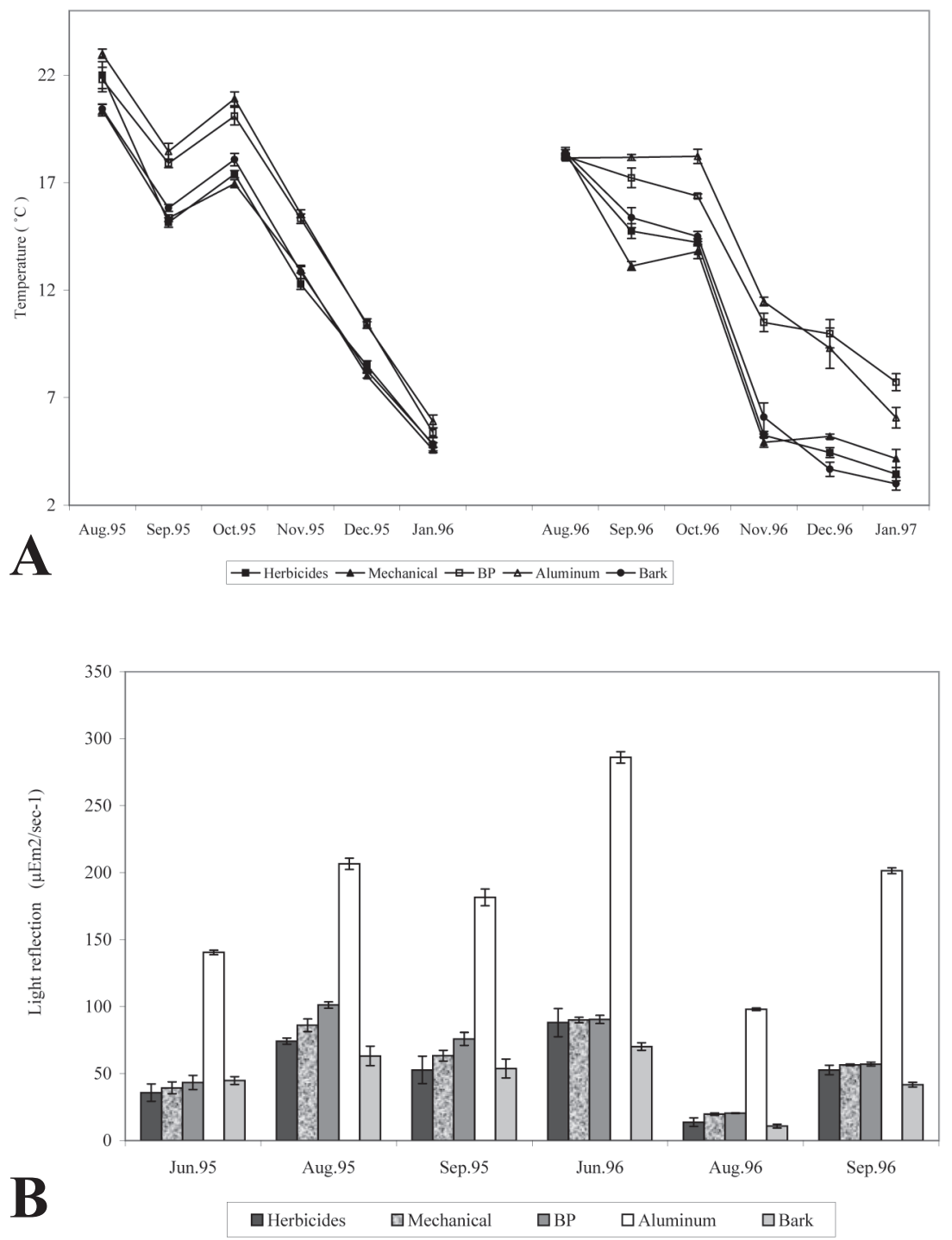

Fig. 2. (A) Soil temperature in different mulching methods, during two seasons (1995, 1996). Bars represent \pm SD. Values are means of four replications of four trees. $\mathrm{n}=20$. (F value: mulching methods, $17.89^{* * * *}$; dates, $299.3^{* * * *}$; mulching $\times$ date, $\left.8.05^{* * *}\right) .{ }^{* * *}$ Significant at $P=0.01$. (B) Relationships between mulching methods and light reflection from the ground to the trees during fruit development period, 1995 and 1996. Bars represent \pm SD. Values are means of four replications, $\mathrm{n}=20$. (F value: mulching methods, $984.4^{* * * *}$; dates, $257.9^{* * * *}$; mulching $\times$ date, $18.67^{* * * *}$ ). ${ }^{* * * *}$ Significant at $P=0.01$. 
Annual weeds had to be removed from the bark-covered area several times. Mechanical mulching showed better weed control than using bark or herbicides (Fig. 1).

Soil conditions and tree growth. Different mulching methods had various effects on soil conditions. Aluminum and BP significantly raised soil temperature during the autumn (September and October), in comparison with herbicides or bark. These two groundcover
Table 1. Tree vegetative growth in different mulching methods.

\begin{tabular}{|c|c|c|c|c|c|}
\hline \multirow[b]{2}{*}{$\begin{array}{l}\text { Mulching } \\
\text { method }\end{array}$} & \multicolumn{3}{|c|}{$\operatorname{TCSA}^{z, y}\left(\mathrm{~cm}^{2}\right)$} & \multicolumn{2}{|c|}{$\begin{array}{l}\text { Tree growth } \\
\text { (Spring 2001) }\end{array}$} \\
\hline & $\begin{array}{c}\text { Winter } \\
1996\end{array}$ & $\begin{array}{c}\text { Spring } \\
1999\end{array}$ & $\begin{array}{c}\text { Relative } \\
\text { change }(\%)\end{array}$ & $\begin{array}{c}\mathrm{Ht} \\
(\mathrm{cm})\end{array}$ & $\begin{array}{l}\text { Spread } \\
(\mathrm{cm})\end{array}$ \\
\hline Herbicides & $37.7 \mathrm{a}^{\mathrm{z}}$ & $69.2 \mathrm{a}$ & 83.5 & $200.3 \mathrm{a}$ & $219.0 \mathrm{ab}$ \\
\hline Mechanical & $30.1 \mathrm{a}$ & $63.1 \mathrm{a}$ & 110.0 & $193.1 \mathrm{a}$ & $206.0 \mathrm{a}$ \\
\hline BP & $35.9 \mathrm{a}$ & $76.3 \mathrm{ac}$ & 112.5 & $214.1 \mathrm{~b}$ & $228.0 \mathrm{bc}$ \\
\hline Aluminum & $41.0 \mathrm{a}$ & $104.5 \mathrm{~b}$ & 154.7 & $218.0 \mathrm{~b}$ & $238.0 \mathrm{c}$ \\
\hline Bark & $34.0 \mathrm{a}$ & $84.1 \mathrm{c}$ & 147.3 & $212.0 \mathrm{~b}$ & $227.0 \mathrm{bc}$ \\
\hline
\end{tabular}

${ }^{\text {zTCSA }}=$ trunk cross sectional area.

${ }^{y}$ Values are means of four replications of four trees each, $\mathrm{n}=80$.

${ }^{\mathrm{x}}$ Means followed by different letters within the same column are significantly different at LSD $=0.05$.
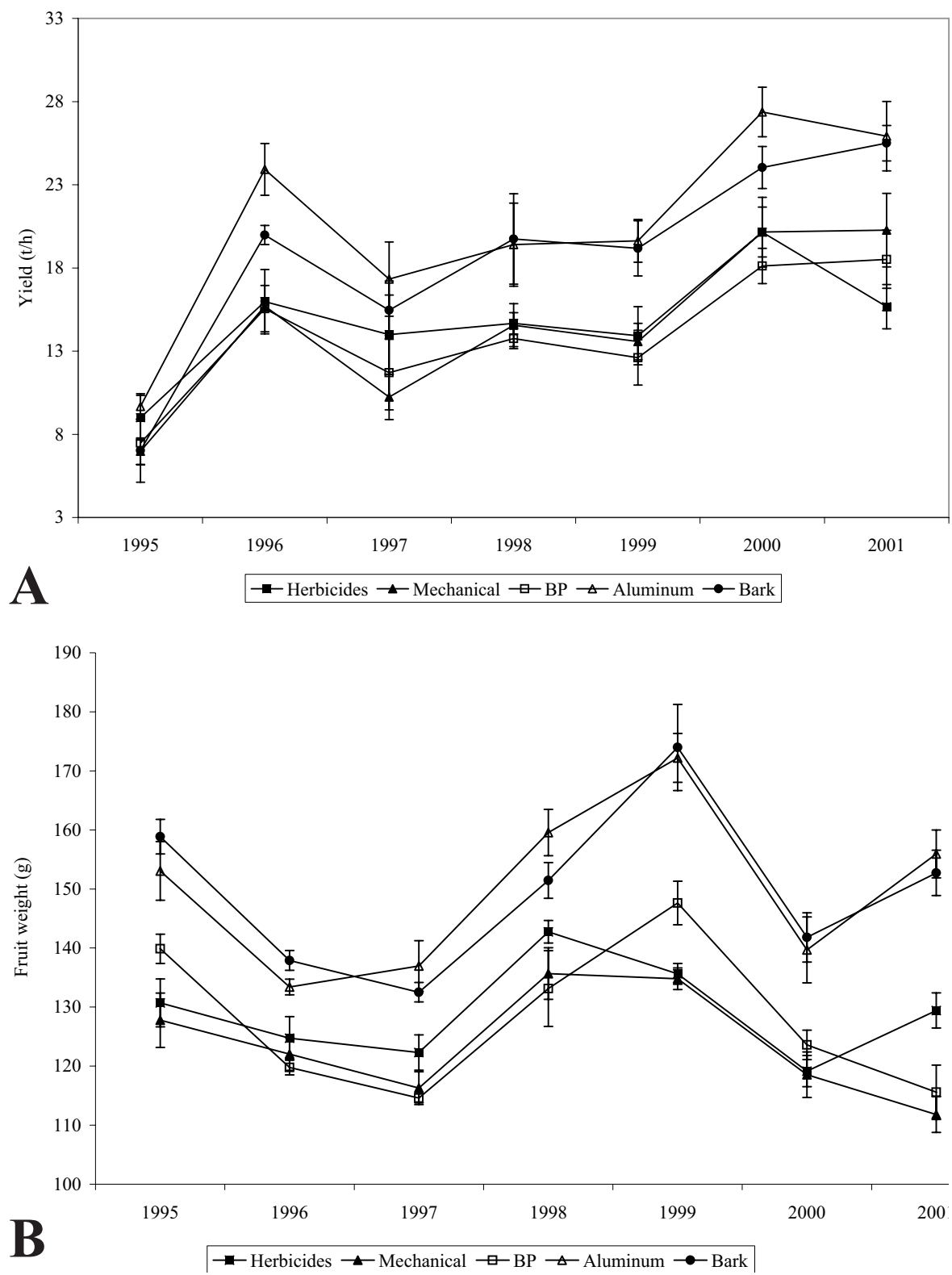

Fig. 3. (A) Tree yield in different mulching methods. Bars represent \pm SD. Values are means of four replications of four trees each, $\mathrm{n}=80$. (F value: mulching methods, $63.31^{* * * *}$; seasons, $133.8^{* * * *}$; mulching $\times$ season, $3.19^{* * * *}$ ). ${ }^{* * *}$ Significant at $P=0.01$. (B) Relationship between application of different GCMSs and fruit weight. Bars represent \pm SD. Values are means of four replications of four trees each, $n=80$. (F value: mulching methods, $50.8^{* * *}$; seasons, $41.1^{* * *}$; mulching $\times$ season, $\left.2.79^{* * *}\right){ }^{* * *}$ Significant at $P=0.01$. materials also raised soil temperature during winter $(P<0.01)$, while no significant differences were noted during summer and between the seasons $(P<0.05$; Fig. $2 \mathrm{~A})$. Moreover, aluminum highly increased light reflection from the ground to the trees during summer and autumn in comparison with other treatments $(P<0.01$; Fig. 2B).

After 4 years of GCMS application, aluminum, bark and BP increased TCSA by $71 \%$, $64 \%$, and $29 \%$ respectively in comparison with using herbicides, and by $44 \%, 37 \%$, and $2 \%$ respectively in comparison with using mechanical mulching (Table 1). In the seventh and last year of the experiment, trees of these three GCMSs were $13 \%, 11 \%$, and $10 \%$ higher and $10 \%$ to $15 \%$ wider spread than trees of mechanical cultivation. No significant differences were noted between the effects of GCMS and using herbicide on tree size $(P<$ 0.05; Table 1).

Yield and fruit weight. During six seasons (1996-2001), total yields were $26 \%$ to $35 \%$ higher $(P<0.01$; Fig. 3A $)$ and fruit weight $18 \%$ higher $(P<0.01$; Fig. 3B) when using aluminum or bark soil covermaterials than with mechanical or chemical weed control. Black polypropylene (BP) increased fruit weight, in 1995, 1999, and 2000 (Fig. 3B) but had no significant effect on yield (Fig. 3A). Significant effects of mulching methods, year and interaction between method and year were found at $P<0.01$.

Fruit quality. Application of GCMSs improved fruit resistance to bruising, while fruit from trees with mechanical cultivation were more sensitive than fruit from GCMSs or herbicides. Covering soil with aluminum or bark caused $15 \%$ to $20 \%$ lower bruise occurrence in comparison with using conventional mulching. BP slightly improved the fruit resistance and had visible effect during only 3 years (Table 2 ). However, bruise susceptibility was significant affected by mulching methods, year and their interactions at $P<0.01$.

Acomparison of the influences of mulching methods on fruit quality directly after harvest showed that covering soil with aluminum led to the significantly highest fruit firmness (Table 3 ), while mechanical cultivation or covering soil with BP gave high acid and sugar content (Table 3).After storage and shelflife, mulching with aluminum or bark resulted in firmer fruit $(P<0.01)$ that had a more acid to sugar ratio $(P<0.05)$ in comparison with conventional mulching (Table 3). No significant effects of interaction between methods and seasons were noted $(P>0.05)$. However, fruit from trees in aluminum or bark mulching lost less of their firmness and acid and sugar content during storage and shelf life in comparison with fruit from other treatments (Table 3).

At harvest, fruit from aluminum covered soil had better red color (lower $h^{\circ}$ ) during the seven seasons while other two GCMSs improved fruit color only during 3 years (Table 4). Compared with conventional mulching methods, fruit from trees with aluminum mulching had also best color after storage and shelf life.

Fruit from trees grown in covered soil showed higher starch score than fruit from 
Table 2. Relationship between application of groundcover material systems and bruise susceptibility of 'Aroma' apple.

\begin{tabular}{|c|c|c|c|c|c|c|c|}
\hline \multirow{2}{*}{$\begin{array}{l}\text { Mulching } \\
\text { method }\end{array}$} & \multicolumn{7}{|c|}{ Bruise $\mathrm{wt}^{2}(\%)$} \\
\hline & 1995 & 1996 & 1997 & 1998 & 1999 & 2000 & 2001 \\
\hline Mechanical & $2.00 \mathrm{~b}$ & $2.01 \mathrm{~b}$ & $1.94 \mathrm{a}$ & $1.50 \mathrm{a}$ & $1.63 \mathrm{a}$ & $1.82 \mathrm{a}$ & $1.62 \mathrm{ab}$ \\
\hline Bark & $1.63 \mathrm{c}$ & $1.72 \mathrm{a}$ & $1.64 \mathrm{~b}$ & $1.30 \mathrm{~b}$ & $1.43 \mathrm{~b}$ & $1.55 \mathrm{~b}$ & $1.52 \mathrm{c}$ \\
\hline
\end{tabular}

${ }^{2}$ Values are means of four replications of eight fruit each, $n=160$.

${ }^{y}$ Means followed by different letters within the same column are significantly different at LSD $=0.05$ (differences between seasons, and interactions between seasons and methods were significant at $P=0.01$ ).

Table 3. Relationship between application of different groundcover material systems and fruit quality at harvest, during storage, and after $7 \mathrm{~d}$ in room temperature (shelf life).

\begin{tabular}{|c|c|c|c|c|c|c|}
\hline \multirow[b]{2}{*}{$\begin{array}{l}\text { Mulching } \\
\text { method }\end{array}$} & \multicolumn{3}{|c|}{ Firmness (N) } & \multicolumn{3}{|c|}{ Acidity/SSC (\%) } \\
\hline & $\begin{array}{c}\text { At } \\
\text { harvest }^{z}\end{array}$ & $\begin{array}{c}\text { After } \\
\text { storage }^{y}\end{array}$ & $\begin{array}{c}\text { After } \\
\text { shelf life }\end{array}$ & $\begin{array}{c}\text { At } \\
\text { harvest }\end{array}$ & $\begin{array}{c}\text { After } \\
\text { storage }\end{array}$ & $\begin{array}{c}\text { After } \\
\text { shelf life }\end{array}$ \\
\hline Herbicides & $53.4 \mathrm{a}^{\mathrm{x}}$ & $39.3 \mathrm{a}$ & $29.5 \mathrm{a}$ & $8.5 \mathrm{a}$ & $5.8 \mathrm{a}$ & $3.6 \mathrm{a}$ \\
\hline Mechanical & $54.6 \mathrm{a}$ & $40.0 \mathrm{a}$ & $30.0 \mathrm{a}$ & $10.0 \mathrm{~b}$ & $6.0 \mathrm{a}$ & $3.6 \mathrm{a}$ \\
\hline $\mathrm{BP}$ & $53.7 \mathrm{a}$ & $38.7 \mathrm{a}$ & $29.0 \mathrm{a}$ & $9.9 \mathrm{~b}$ & $5.6 \mathrm{a}$ & $3.4 \mathrm{a}$ \\
\hline Aluminum & $57.8 \mathrm{~b}$ & $46.0 \mathrm{~b}$ & $34.5 \mathrm{~b}$ & $8.8 \mathrm{a}$ & $7.3 \mathrm{~b}$ & $5.9 \mathrm{~b}$ \\
\hline Bark & $56.8 \mathrm{ab}$ & $45.0 \mathrm{~b}$ & $33.7 \mathrm{~b}$ & $9.0 \mathrm{a}$ & $7.0 \mathrm{~b}$ & $4.3 \mathrm{c}$ \\
\hline
\end{tabular}

${ }^{\mathrm{z}}$ Values are means of 7 years, four replications of four trees each (five fruit per tree), $\mathrm{n}=400$.

yalues are means of 7 years, four replications of five fruits, $n=100$.

${ }^{y}$ Means followed by different letters within the same column are significantly different at LSD $=0.05$ (differences between mulching methods or between seasons were significant at $P=0.05$. Interaction between methods and seasons was not significant).

trees grown with conventional mulching (Fig. 4), indicating that GCMSs advanced fruit ripening by $5 \mathrm{~d}$ (Fig. 4). Mulching methods and their interaction significantly influenced the starch score, indicating fruit ripening $(P<$ 0.05 to 0.01 ).

Fruit storability. More than $80 \%$ of fungal decay during storage was caused by Pezicula spp. (data not shown). Replacement of herbicides or mechanical cultivation with bark or aluminum cover increased 'Aroma' resistance to storage decay. Using aluminum significantly decreased these losses by $75 \%$, during six seasons in comparison with using herbicides and during five seasons in comparison with using mechanical cultivation. Application of bark or BP significantly decreased losses by $40 \%$ and $25 \%$, respectively. These effects were shown during four seasons in comparison with using herbicides and only during two seasons in comparison with using mechanical cultivation (Table 5). Mulching methods, year, and their interaction significantly affected fruit decay $(P<0.01)$.

\section{Discussion}

The use of some GCMSs such as aluminum and BP can improve soil cation exchange capacity and increase fruit mineral content, which might lead to an improvement of fruit quality (Lang et al., 2001). GCMSs can also increase feeder roots (Lang et al., 2001) and photosynthetic activity of the tree (Mathieu and Aure, 2000), thereby resulting in healthier trees, with more vegetative growth and wider trunk cross-sectional area. Trunk cross-sectional area can be used to estimate the bearing potential of apple trees (Westwood, 1993). This is in accordance with the findings in the present study, with especially aluminum mulches leading to improved vegetative growth of the apple trees. Higher production of marketable fruit might also be attributable to such better tree conditions (Lang et al., 2001).

Fruit quality is a complex character, determined by several characters, such as coloration, firmness, SSC and acidity. Each of these co-characters are determined by differ- ent factors and in various ways influenced by different GCMSs. For example, light regulates directly development of apple color through stimulation of anthocyanin accumulation and chlorophyll degradation in the fruit peel (Zhiqiang et al., 1999). Several authors have suggested that covering orchard floors with reflecting films should lead to an increase in the fruit coloration (Andris et al., 1998; Mathieu and Aure, 2000; Zhiqiang et al., 1999). In the present study, 'Aroma' fruit from trees grown in aluminum-covered soil had the best coloration compared with other GCMSs and conventional mulching methods. Thus, the increased fruit coloration, when using aluminum, might be due to an increase in light intensity by reflectance, which in turn might lead to a stimulation of the anthocyanin synthesis. In addition, covering soils with foils has generally been found to improve soil conditions and mineral content of leaves (Lang et al., 2001; Merwin and Stiles, 1994; Oliviera and Merwin, 2001).

Firmness and acid to sugar ratio changed in 'Aroma' apples during storage and shelf life. A considerable loss of fruit acid to sugar ratio could be avoided by using aluminum and bark mulching, which protected also from lower fruit firmness. 'Aroma' storability was thereby improved by the use of aluminum and bark mulching. One reason for the better quality of fruit after the use of GCMSs, and especially aluminum mulching, might be that the use of cover systems leads to a modification of the soil temperature, an increase of the soil moisture and a lower soil $\mathrm{pH}$ during the growth period.

Compared with conventional mulching methods, the use of GCMSs advanced fruit ripening possibly due to a more active photosynthesis, and thereby higher respiration rate

Table 4. Fruit color characteristics represented as hue angle $\left(\mathrm{h}^{\circ}\right)$ due to application of different groundcover material systems.

\begin{tabular}{|c|c|c|c|c|c|c|c|}
\hline \multirow{2}{*}{$\begin{array}{l}\text { Mulching } \\
\text { method }\end{array}$} & \multicolumn{7}{|c|}{ Year } \\
\hline & 1995 & 1996 & 1997 & 1998 & 1999 & 2000 & 2001 \\
\hline Herbicides & $79.4^{y} a^{x}$ & $85.9 \mathrm{a}$ & $75.5 \mathrm{a}$ & $100.2 \mathrm{a}$ & $102.0 \mathrm{a}$ & $95.8 \mathrm{a}$ & $85.3 \mathrm{a}$ \\
\hline BP & $85.3 \mathrm{a}$ & $81.0 \mathrm{ac}$ & $78.1 \mathrm{a}$ & $79.5 \mathrm{~b}$ & $87.5 \mathrm{bc}$ & $91.7 \mathrm{ac}$ & $80.9 \mathrm{a}$ \\
\hline Aluminum & $58.3 \mathrm{~b}$ & $61.3 \mathrm{~b}$ & $64.8 \mathrm{c}$ & $53.7 \mathrm{c}$ & 87.9 bc & $72.7 \mathrm{~b}$ & $60.1 \mathrm{~b}$ \\
\hline Bark & $83.1 \mathrm{a}$ & $75.7 \mathrm{c}$ & $76.7 \mathrm{a}$ & $65.4 \mathrm{~d}$ & $80.1 \mathrm{c}$ & $84.3 \mathrm{c}$ & $70.9 \mathrm{c}$ \\
\hline \multicolumn{8}{|c|}{ After cold storage 4 months, 1 week at room temperature } \\
\hline BP & $84.3 \mathrm{~b}$ & $79.0 \mathrm{a}$ & $74.5 \mathrm{c}$ & $77.4 \mathrm{~b}$ & $87.0 \mathrm{ab}$ & $90.8 \mathrm{ac}$ & $78.1 \mathrm{a}$ \\
\hline Aluminum & $52.0 \mathrm{c}$ & $58.2 \mathrm{~b}$ & $60.3 \mathrm{a}$ & $50.0 \mathrm{c}$ & $87.3 \mathrm{ab}$ & $66.3 \mathrm{~b}$ & $54.2 \mathrm{~b}$ \\
\hline Bark & $82.0 \mathrm{ab}$ & $72.8 \mathrm{a}$ & $73.8 \mathrm{c}$ & $61.2 \mathrm{~d}$ & $78.0 \mathrm{~b}$ & $83.1 \mathrm{c}$ & $67.1 \mathrm{c}$ \\
\hline
\end{tabular}

${ }^{2}$ Values are means of four replications and twenty fruit each, $n=400$.

${ }^{y}$ Means followed by different letters within the same column are significantly different at LSD $=0.05$ (differences between mulching methods or between interaction between methods and seasons were significant at $P=0.05$ )

${ }^{x}$ Values are means of four replications of five fruit each, $n=100$. 
and metabolism (Mathieu and Aure, 2000). In our investigation no negative effects on the storability after the use of GCMSs were found. However, the faster ripening of the fruit after the use of GCMSs makes the issue of picking fruit at the optimum date important. Picking the apples at the wrong time in relation to the short ripening period can decrease the storage potential of fruit and waste the positive effect of GCMSs on their storability.

GCMSs caused healthier and cleaner fruit that may have resulted in less contamination with pathogens at harvest and more resistance to fungal decay during storage. Moreover, aluminum and bark were found to protect against bruising. No other reports have been dealing with relationships between bruising and GCMSs. As bruising is one of the major problems when cultivating 'Aroma' apples, and as the cultivar sensitivity increases directly with fruit size (Ericsson and Tahir 1996b), our findings that aluminum and bark mulches, similarly increase 'Aroma' apples weight, and protect against bruising during storage and shelf life, are of great importance. These findings are similar to what has been reported in a previous study showing that higher fruit firmness, better red coloration and high calcium content improve 'Aroma' fruit storability and their resistance to bruising (Tahir, 1998).

Interactions between mulching method and year were found for yield, fruit weight, bruise susceptibility, starch score and storage decay. Thus, a simple relationship between a certain

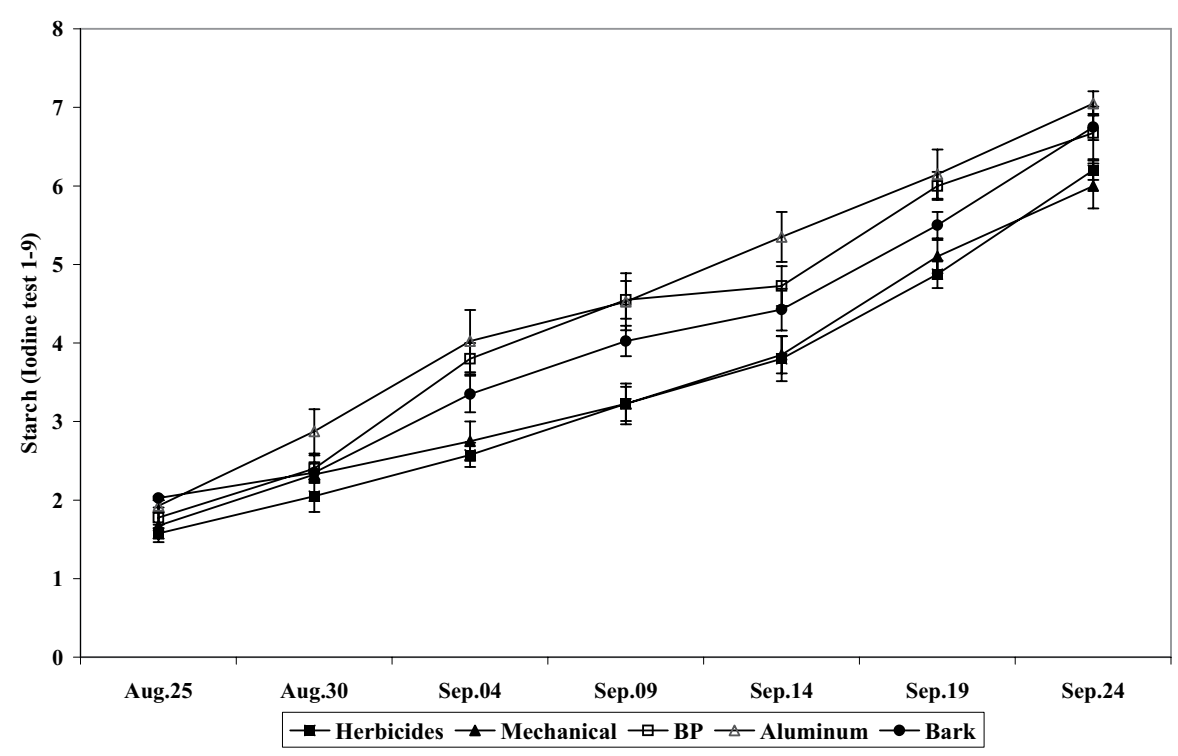

Fig. 4. Conversion of fruit starch due to different mulching methods. Bars represent \pm SD. Values are means of 4 years (four replications of four trees and two fruit each), $\mathrm{n}=160$. (F value: mulching methods, 29.6 $6^{* * *}$; seasons, 276.3**; mulching $\times$ season, $\left.1.17^{\mathrm{NS}}\right)$. ${ }^{* * *}$ Significant at $P=0.01$.

mulching method and the mentioned quality parameters are not present, and are also influenced by seasonal weather variations.

The results in the present investigation thus show that the GCMSs, and especially aluminum and bark, influence the 'Aroma' apple towards better quality and also towards better yield compared with conventional mulching methods. In general, these GCMSs are also better methods concerning human health and environment. In conclusion, aluminum can be suggested as the first and a good alternative to mechanical or chemical mulching of 'Aroma' orchard because it was more effective than bark mulching considering weed growth, yield, and fruit coloration.

\section{Literature Cited}

Andris, H.L., C.H. Crisosto, and Y.L. Grossman. 1998. The use of reflective films to improve the apple fruit red color. Plasticulture 116:33-42.

Bhutani, V.P., S.S. Raina, and U.U. Khokhar. 1995. A note the effect of different floor management systems on cropping and quality of apple. Haryana J. Hort. Sci. 24:35-38.

Dris, R., R. Niskanen, and E. Fallahi. 1999. Relationship between leaf and fruit minerals and fruit quality attributes of apples grown under northern conditions. J. Plant Nutr. 22:1839-1851.

Darbellay, C. 1997. Young fruitplantings. Soil management. Arboricult. Fruit 506:26-30.

Ericsson, N.A. 1982. Influence of harvest time on yield, fruit growth and quality in three apple cultivars. SLU Rpt. 23:9-16.

Ericsson, N.A. 1987. A trial with herbicides in an apple orchard 1975-1979. SLU Rpt. 49:1-2.

Ericsson, N.A. and I.I. Tahir. 1996. Studies on apple bruising.
Table 5. Application of different groundcover material systems and occurrence of storage decay. ${ }^{2}$

\begin{tabular}{|c|c|c|c|c|c|c|c|}
\hline \multirow{2}{*}{$\begin{array}{l}\text { Mulching } \\
\text { method }\end{array}$} & \multicolumn{7}{|c|}{ Decay (\%) } \\
\hline & 1995 & 1996 & 1997 & 1998 & 1999 & 2000 & 2001 \\
\hline Mechanical & $7.5 \mathrm{a}$ & $9.0 \mathrm{a}$ & $6.8 \mathrm{a}$ & $1.3 \mathrm{ab}$ & $6.5 \mathrm{bc}$ & $3.8 \mathrm{ab}$ & $4.5 \mathrm{ab}$ \\
\hline Aluminum & 2. c & $2.5 \mathrm{c}$ & $1.0 \mathrm{~b}$ & $0.0 \mathrm{~b}$ & $0.0 \mathrm{~d}$ & $1.3 \mathrm{c}$ & $1.8 \mathrm{c}$ \\
\hline Bark & $5.5 \mathrm{~b}$ & $3.5 \mathrm{c}$ & $2.0 \mathrm{~b}$ & $1.5 \mathrm{ab}$ & $4.8 \mathrm{ab}$ & $2.8 \mathrm{bc}$ & $2.5 \mathrm{c}$ \\
\hline
\end{tabular}

${ }^{2}$ Values are means of four replications of four fruits each, $\mathrm{n}=100$.

${ }^{\mathrm{y}}$ Means followed by different letters within the same column are significantly different at LSD $=0.05$ (differences between seasons, and interactions between seasons and methods were significant at $P=0.01$ ).
I. Estimation of incidence and susceptibility differences in the bruising of three apple cultivars. Acta.Agr. Scand. Sect. B. Soil and Plant Sci. 46:209-213.

Ericsson, N.A. and I.I. Tahir. 1996b. Studies on apple bruising. II. The effects of fruit characteristics, harvest date and precooling on bruise susceptibility in three apple cultivars. Acta. Agr. Scand. Sect. B. Soil and Plant Sci. 46:214-217.

Fausett, J.B. and C.R. Rom. 2001. The effects of transitioning a mature high-density orchard from standard herbicide ground cover management system to organic groundcover management systems. Res. Ser. Ark. Agr. Expt.Sta. 483:33-36.

Lang, A., M.H. Behboudian, J. Kidd, H. Brown, J.W. Palmer, and J.N. Wunsche. 2001. Mulch enhances apple storage quality. Acta Hort. 557:433-439.

Mage, F. and G. Skogerbo. 1992. Orchard soil management systems effects on growth and fertility of apple trees. Nor. J. Agr. Sci. 6:121-132.

Mathieu, V. and D. Aure. 2000. Apple. A reflective film for improving color. Info-Paris 160:37-41.

McGuire, R.G. 1992. Reporting of objective color measurements. HortScience. 27:1254-1255.

Meberg, K.R., K.Haffner, and H.J.Rosenfeld. 2000. Storage and shelf-life of apples grown in Norway. I. Effects of controlled atmosphere storage on 'Aroma'. Gartenbauwissenchaft 65:9-16.

Merwin, I.A. and W.C. Stiles. 1994. Orchard groundcover management impacts on apple tree growth and yield, and nutrient availability and uptake. J.Amer. Soc. Hort. Sci. 119:209-215.

Merwin, I.A. and W.C. Stiles, 1994. Orchard groundcover management impacts on soil physical properties. J. Amer. Soc. Hort. Sci. 119:216-222.

Mika, A., D. Krzewinska, and T. Olszewskiet. 1998. Effects of mulches, herbicides and cultivation as orchard groundcover management systems in young apple orchard. Fruit Sci. Rpt. 6:1-13.

Oliveira, M.T. and I. Merwin, 2001. Soil physical conditions in a New York orchard after years under different groundcover management systems. Plant Soil 234:233-237

Rein, A. 1996. Apple storage disorders (original title in Swedish: Skador på äpplen vid Inlagring). Swedish Board of Agr. Agro. Info. 3810 Gvarv.

Rifai, M.N, T. Astatkie, M. L. Bartosova, and J. Gadus. 2002. Effect of two different thermal units and three types of mulch on weeds in apple orchards. J. Env. Eng. Sci. 1:331-338.

Tahir, I.I. 1998. Relation between apple trees nutrition and bruise susceptibility. Scand. Assn. Agr. Sci. NJF. Conf. Landskrona-Sweden 293.

Tomala, K. 1999. Orchard factors affecting fruit storage quality and prediction harvest date of apple. Acta Hort. 485:373-382.

Weibel, F.P. 1996. Soil management methods with reduced herbicides application for apples. Obst-Weinbau. 132:67 (abstr.).

Westwood, M.N. 1993. Temperate-zone pomology, physiology and culture. $3 \mathrm{~d}$ ed. Timber press, Portland, Ore.

Wieniarska, J., E. Kaufmane, and A. Libek. 2000. Living mulches in the apple orchard, an alternative for herbicides. Intl. Conf. Fruit Prod. Fruit Breed. Estonia. p. 104-106.

Ystaas, J. and O. Froynes. 1993. Performance of Red Gravenstein, Summerred and Aroma on apple rootstocks M9, M26 and MM106 over 14 years. Nor. J. Agr. Sci. 7:261-266.

Zhiqiang, Ju., Y. Duan, and Ju. Zhiguo.1999. Effects of covering the orchard floor with reflecting film on pigment accumulation and fruit coloration in 'Fuji' apples. Sci. Hort. 82:47-56. 